\title{
Rilievo tridimensionale e virtualizzazione di sculture in marmo del Museo Archeologico Nazionale di Luni
}

\author{
Carlo Battini \\ Marcella Mancusi \\ Mauro Stallone
}

\section{Abstract}

II presente contributo vuole descrivere le scelte e le metodologie operative che hanno portato all'acquisizione tridimensionale di cinque sculture in marmo fino ad oggi conservate all'interno del Museo Archeologico Nazionale di Luni. Grazie alla Convenzione Quadro sottoscritta tra la Direzione regionale Musei della Liguria e il Dipartimento di Ingegneria Civile, Chimica e Ambientale (DICCA) dell'Università degli Studi di Genova è stato possibile attivare uno specifico accordo attuativo all'interno del quale sono stati definiti gli obiettivi e le modalità operative per l'esecuzione dei rilievi 3D. Tale intervento si pone come conseguenza della decisione di demolire l'edificio museale lunense e quindi della necessità di prowedere alla rimozione di tutti i reperti in esso custoditi. La prima fase di rilevamento ha avuto infatti lo scopo di documentare lo stato di fatto delle opere e del loro particolare sistema di esposizione che sarebbe stato necessario rimuovere in previsione della movimentazione. La successiva integrazione delle acquisizioni con le superfici di appoggio, non visibili prima della demolizione delle strutture di sostegno, ha consentito di registrare tutte le informazioni necessarie alla corretta progettazione di idonei supporti utili al loro futuro allestimento. Gli stessi modelli sono poi stati resi fruibili via web su una piattaforma open source.

\section{Parole chiave}

Luni, museo, sculture, structure from motion, documentazione.

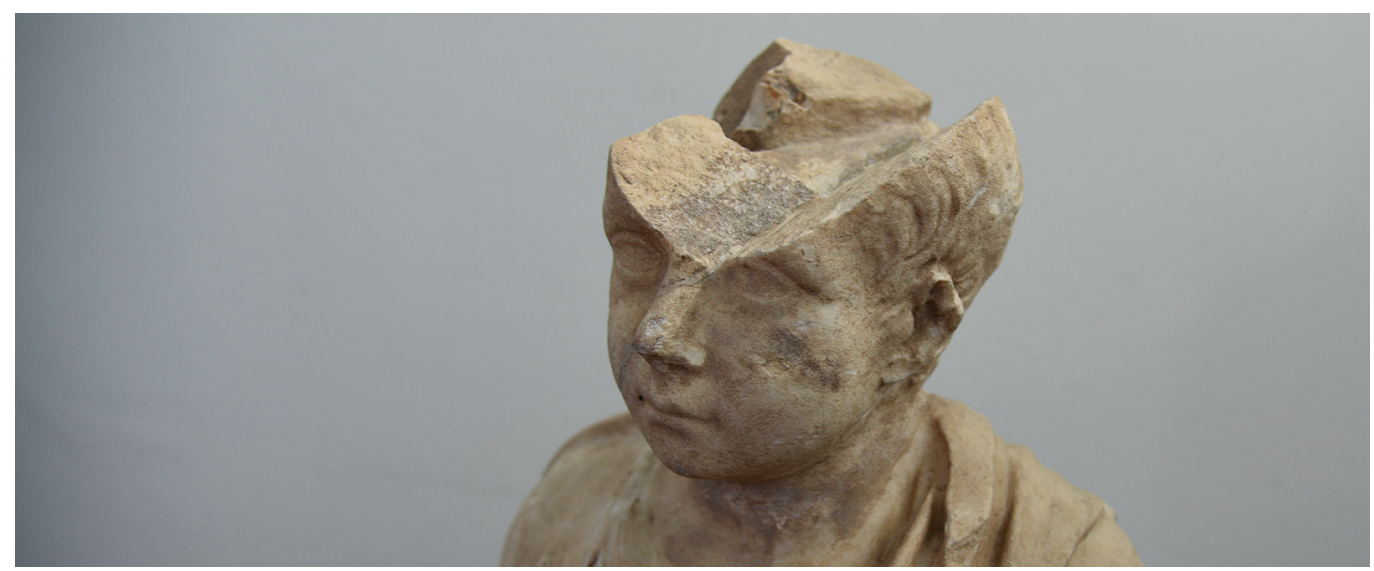




\section{Introduzione}

II sito archeologico di Luni sorge nell'estremo Levante ligure e conserva i resti della colonia romana di Luna, fondata nel I 77 a.C.e abitata ininterrottamente fino agli inizi del XIII secolo. Durante la fase imperiale la città acquisisce fama e ricchezza grazie allo sfruttamento dei bacini marmiferi delle Alpi Apuane che ricadono nel suo territorio; di lì il marmo viene esportato in tutto l'impero, in particolare a Roma.

Nonostante l'intensa spoliazione avvenuta in antico, si dispone di un discreto corpus di sculture figurate che risulta oggi distribuito in vari sedi espositive a causa della complessa storia dell'esplorazione del centro che, iniziata nei primi decenni dell'800, ha portato alla formazione di importanti collezioni private [De Pascale, Gandolfi 20 I7].A partire dalla metà del '900 è iniziata - ed è tutt'ora in corso - la ricerca archeologica condotta dall'organo di tutela di quello che oggi è il Ministero della Cultura, che ha dato origine da una parte ad una vasta bibliografia scientifica [I], dall'altra la formazione dell'area archeologica e del museo destinati alla pubblica fruizione, così come sono attualmente.

\section{Le sculture in marmo}

Le statue oggetto del rilievo 3D hanno storie piuttosto diverse tra loro, ma sono accomunate dal marmo locale impiegato per la loro esecuzione [2] e dal fatto di essere state create in un arco di tempo a cavallo tra la fine del I sec. a.C. e la metà del secolo successivo. Tale periodo corrisponde al momento di massima fioritura per Luni poiché, a seguito della ricchezza derivata dallo sfruttamento intensivo della cave di marmo, la città subisce una profonda trasformazione urbanistica e architettonica all'insegna della monumentalizzazione. A tale risultato concorre appunto anche la statuaria, utilizzata in prevalenza per abbellire spazi pubblici di varia natura. Nello specifico le sculture in esame riproducono quattro soggetti maschili, di cui tre adulti, ed uno femminile; tutte risultano in parte lacunose e - ad eccezione di un unico caso - sono prive del volto.

Tra i ritrovamenti più antichi si segnalano la statua femminile con cornucopia e quella maschile con toga (fig. I), entrambe venute alla luce nel 1837 nel corso delle esplorazioni condotte dall'architetto Carlo Promis, Ispettore dei Monumenti di Antichità dei Regi Musei, nei terreni di proprietà del Marchese Angelo Remedi. L'area del recupero è quella che oltre un secolo dopo è stata identificata come il bacino fontana che si sviluppa su tre lati intorno al tempio capitolino (fig. 2). Le due sculture sono selezionate per le collezioni sabaude, ma esposte nel Museo di Antichità di Torino solo nel 1878 e, di lì a poco, nella IV Esposizione Nazionale di Belle Arti che si tiene nella stessa città; a distanza di quasi un secolo, nel 1963, rientrano a Luni per l'inaugurazione del museo in fase di allestimento [Durante, Gervasini 2017].

La statua femminile, abbigliata con un'elegante veste ed un mantello, ritrae, con una modalità spesso utilizzata durante l'impero a fini propagandistici, un personaggio della famiglia imperiale associandolo allimmagine di una divinità o di una personificazione di un concetto astratto, in questo caso Abundantia o Fortuna per via della presenza della doppia comucopia da cui fuoriescono frutti (fig. 3) [Frova 1983, pp. 73-75, fig. 28; Marmora Lunensia erratica, pp. 5 I -53]. II riconoscimento del personaggio è affidato al volto-ritratto di cui resta ben visibile l'incavo per l'alloggio. Analoga cavità si conserva anche nella statua maschile che indossa una toga fittamente panneggiata (fig. 4) e riproduce un preciso schema iconografico in cui un braccio è piegato a sostenere il volumen mentre l'altro è disteso in avanti [Frova 1983, pp. 76-77, fig. 30; Marmora Lunensia erratica, pp. 54-55].

Più lineare è la sorte delle sculture del Capite velato e del principe giulio-cluadio rinvenute a seguito delle importanti campagne di scavo realizzate negli anni '70 del secolo scorso, rispettivamente ad est e a nord del Capitolium, in aree contigue a quelle da cui provengono le statue descritte sopra.

II Capite velato, privo della metà inferiore [Frova 1983, p. 78, nota n. 59], presenta caratteristiche che ne consentono l'identificazione come pontifex nell'atto di compiere un sacrificio, rituale che era necessario si svolgesse appunto con il capo coperto. Anche in questo caso 

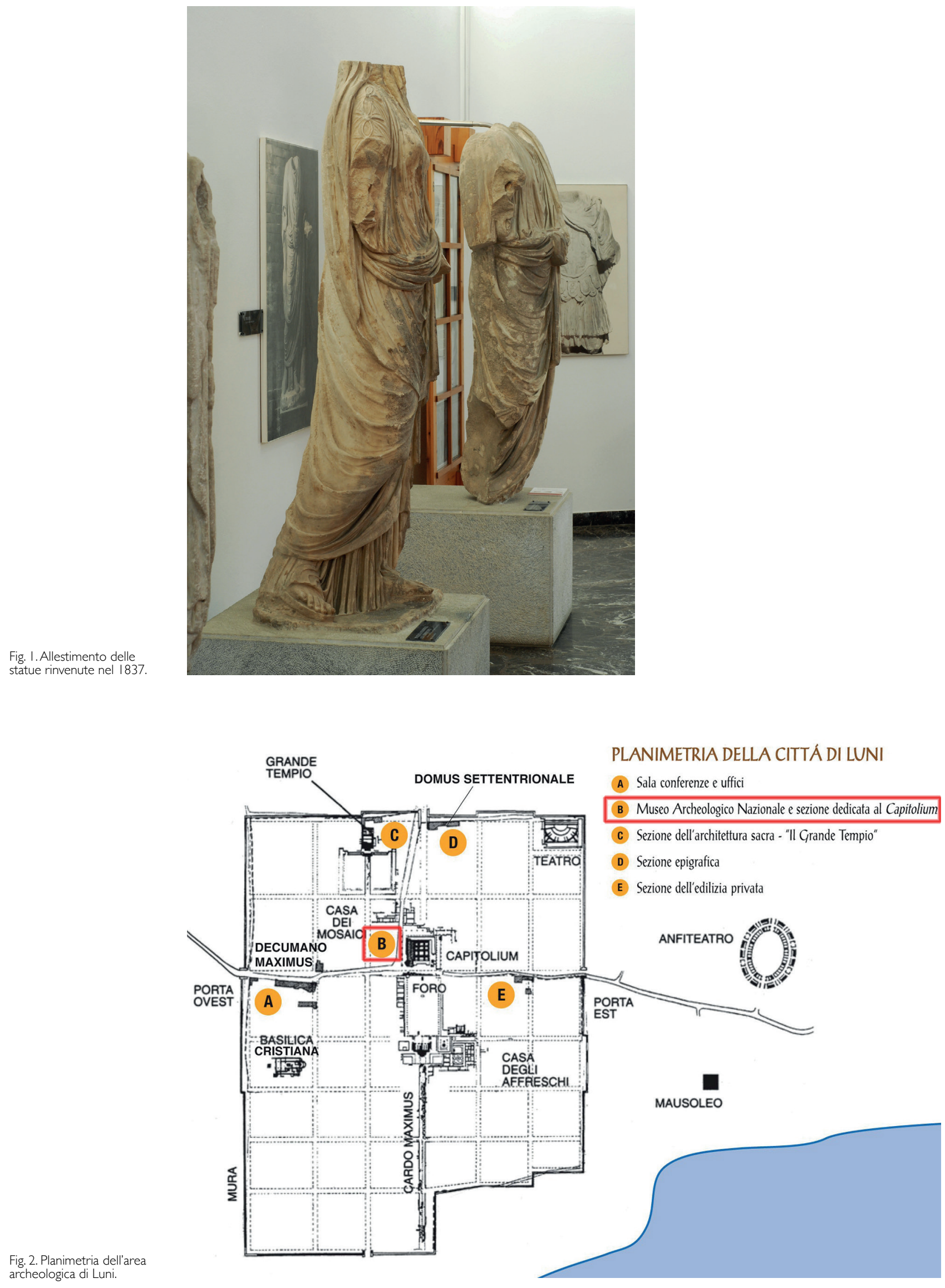


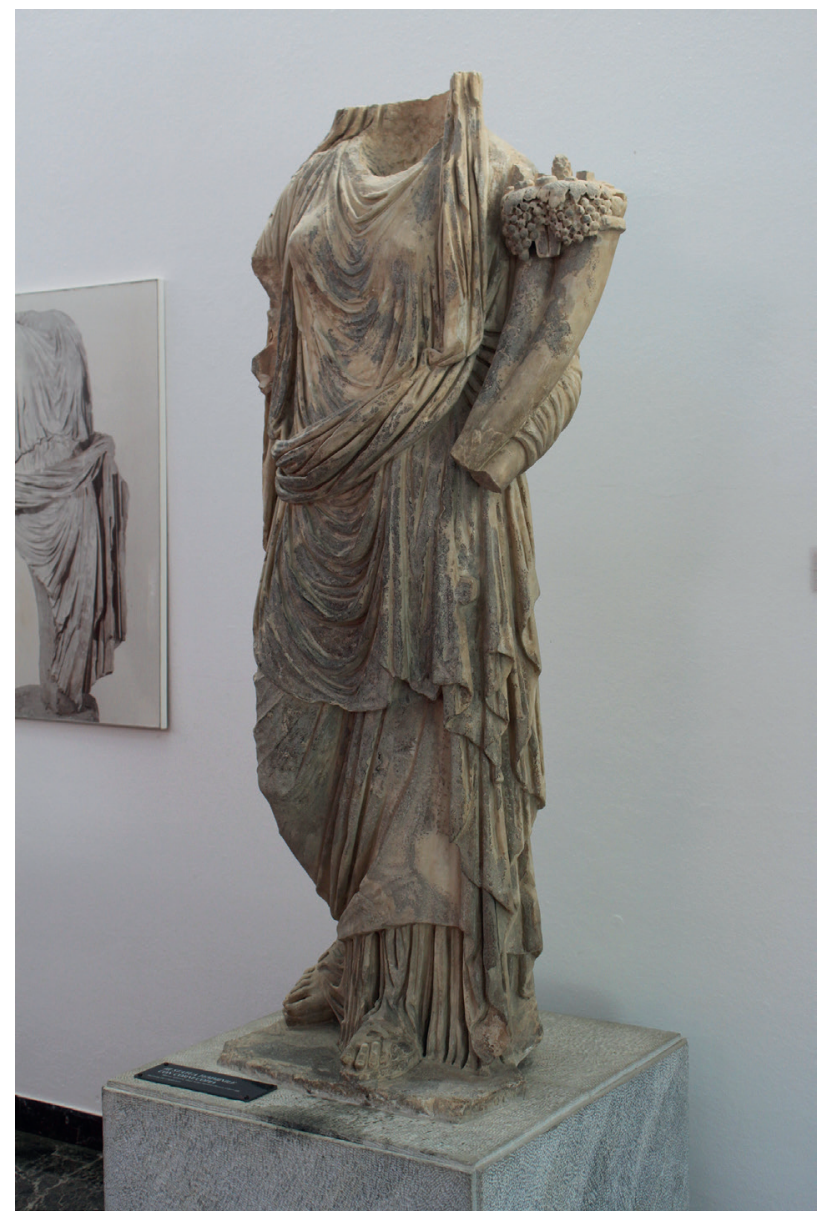

la perdita del volto non consente di stabilire se il personaggio raffigurato fosse Augusto o un suo successore; si tenga conto inoltre che tale iconografia ebbe grande successo anche al di fuori della cerchia imperiale.

Molto probabilmente apparteneva invece a un giovane principe la statua di fanciullo con bulla - tipico ornamento dell'infanzia - il quale esprime il suo status per mezzo dell'anello visibile all'anulare sinistro (fig. 5).

L'ultima scultura del gruppo è entrata a far parte dell'allestimento museale solo nel 2016 dopo essere stata sottratta a chi la deteneva illegalmente. Non se ne conosce il luogo di provenienza, tuttavia è lunense il marmo con cui è realizzata. L'opera, priva della parte superiore, rientra nella tipologia di statue virili in nudità eroica con cui si ritraggono indifferentemente facoltosi cittadini, imperatori e divinità (fig. 6) [Mancusi, Chiarenza 20 I 8, pp. 21, 22].

\section{La nascita del progetto di collaborazione}

II museo, destinato a raccogliere ed esporre i principali reperti rinvenuti nell'area archeologica lunense, è stato inaugurato nel 1964 su progetto dell'architetto Aldo Grillo. Dalla sua inaugurazione ha subito diversi cambiamenti e modifiche nel suo impianto espositivo e nella selezione dei reperti [Lusuardi, Massari, Rossignani 1980], pur mantenendo sostanzialmente invariato sino ai giorni nostri l'allestimento della statuaria di grandi dimensioni all'interno dell'ampia sala poligonale nel corpo a sud dell'edificio (fig. 7).

A seguito della Delibera della Giunta Regionale n. 216 del 2017, che ha innalzato la classe di rischio della zona di Luni, si è reso necessario avviare le indagini per la definizione del rischio sismico di tutti i fabbricati dell'area archeologica. Le verifiche dei tecnici, considerata la parti- 

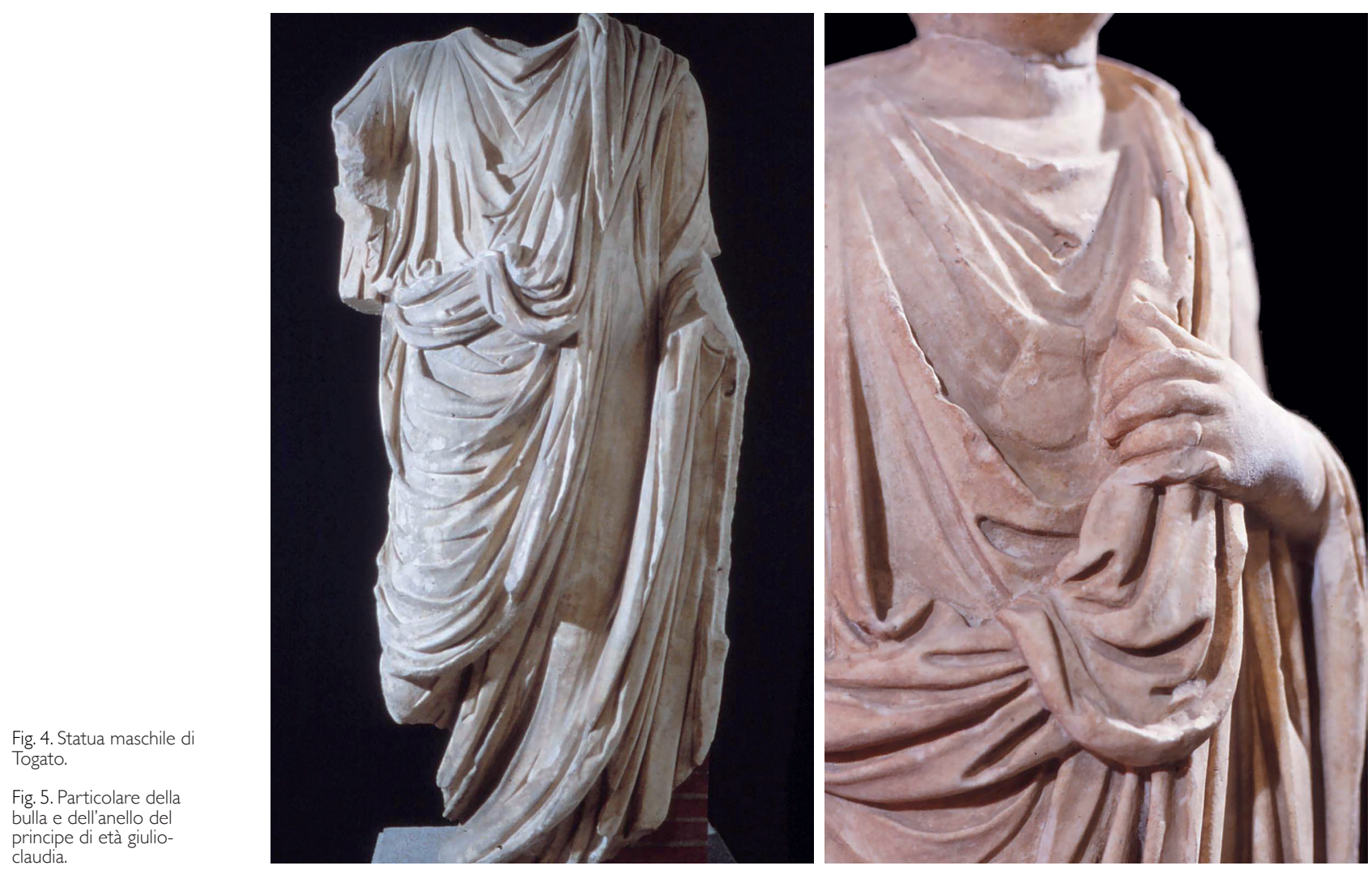

rincipe di eta claudia.

colare natura dell'edificio museale, legata anche alla peculiarità di insistere direttamente sulla quota del piano archeologico oltre che in corrispondenza di importanti strutture architettoniche, hanno evidenziato l'impossibilità di adeguare il Museo all'attuale normativa antisismica. Alla luce di tali dati e al fine di garantire la sicurezza di visitatori e lavoratori, l'edificio è stato chiuso al pubblico nel 2018. Da qui la necessità di individuare una soluzione alternativa che prevedesse lo spostamento dei reperti, l'allestimento di nuovi spazi espositivi e la demolizione dell'edificio dichiarato non più agibile.

In previsione del necessario intervento di demolizione dell'edificio, è stato predisposto un articolato progetto finalizzato allo svuotamento del museo e contestuale movimentazione di tutte le opere in esso contenute. Nel caso delle cinque sculture lapidee si è scelto di approfondirne lo studio e la documentazione, considerate le pochissime notizie d'archivio emerse relativamente alla storia degli interventi precedenti, alle metodologie di restauro ed alle modalità di allestimento. Le statue, infatti, erano state posizionate su parallelepipedi in cemento rivestiti da lastre in marmo [3] che a volte occultavano il reale sistema di vincolo in corrispondenza delle basi di appoggio [4].

Sulla base di una Convenzione Quadro, stipulata tra la Direzione regionale Musei (DRM) della Liguria ed il Dipartimento di Ingegneria Civile, Chimica e Ambientale (DICCA) dell'Università degli Studi di Genova è stato possibile attivare uno specifico accordo attuativo per il rilievo tridimensionale delle cinque sculture lapidee tramite strumentazione no-contact. Uno degli obiettivi del progetto è stato quello di acquisire tutte le informazioni relative allo stato di fatto delle opere al fine di documentare il loro stato di conservazione e registrare la loro storia conservativa, prima dell'intervento di svuotamento e successiva demolizione del museo. Ė stata pertanto avviata una prima campagna di acquisizioni che ha avuto come oggetto il rilevamento delle superfici lapidee e dei basamenti che ne costituivano il sistema espositivo. A seguito dell'intervento di demolizione dei piedistalli, necessario alla movimentazione dei reperti (fig. 8), è stato possibile procedere con la seconda campagna di acquisizioni per il rilevamento delle superfici di appoggio al fine di completare i modelli tridimensionali 
Fig. 6. Statua virile in
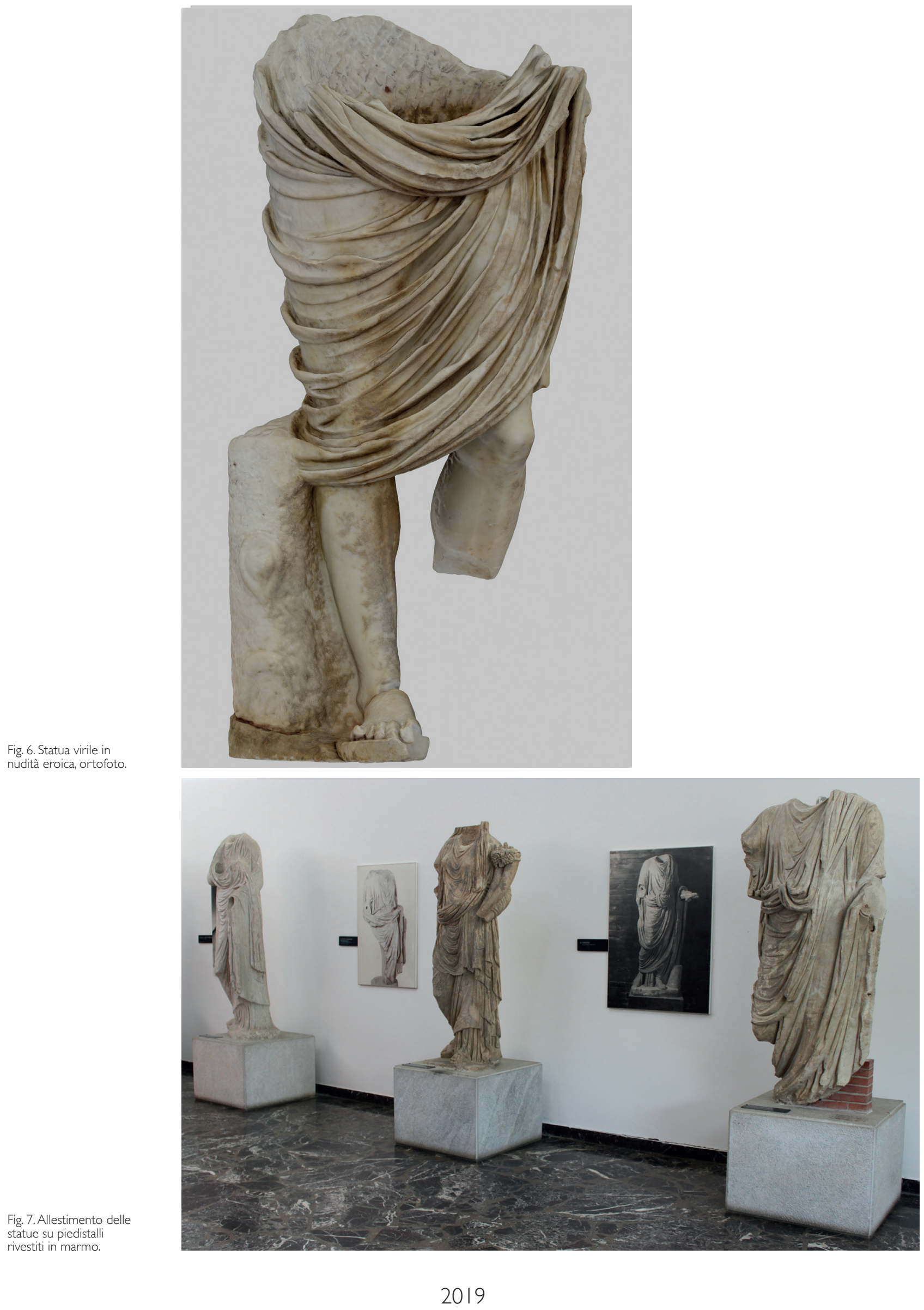
Fig. 8. Fase di

movimentazione delle statue dopo la parziale demolizione dei piedistalli.

Fig. 9. Area non rilevabile prima della demolizione del piedistallo.
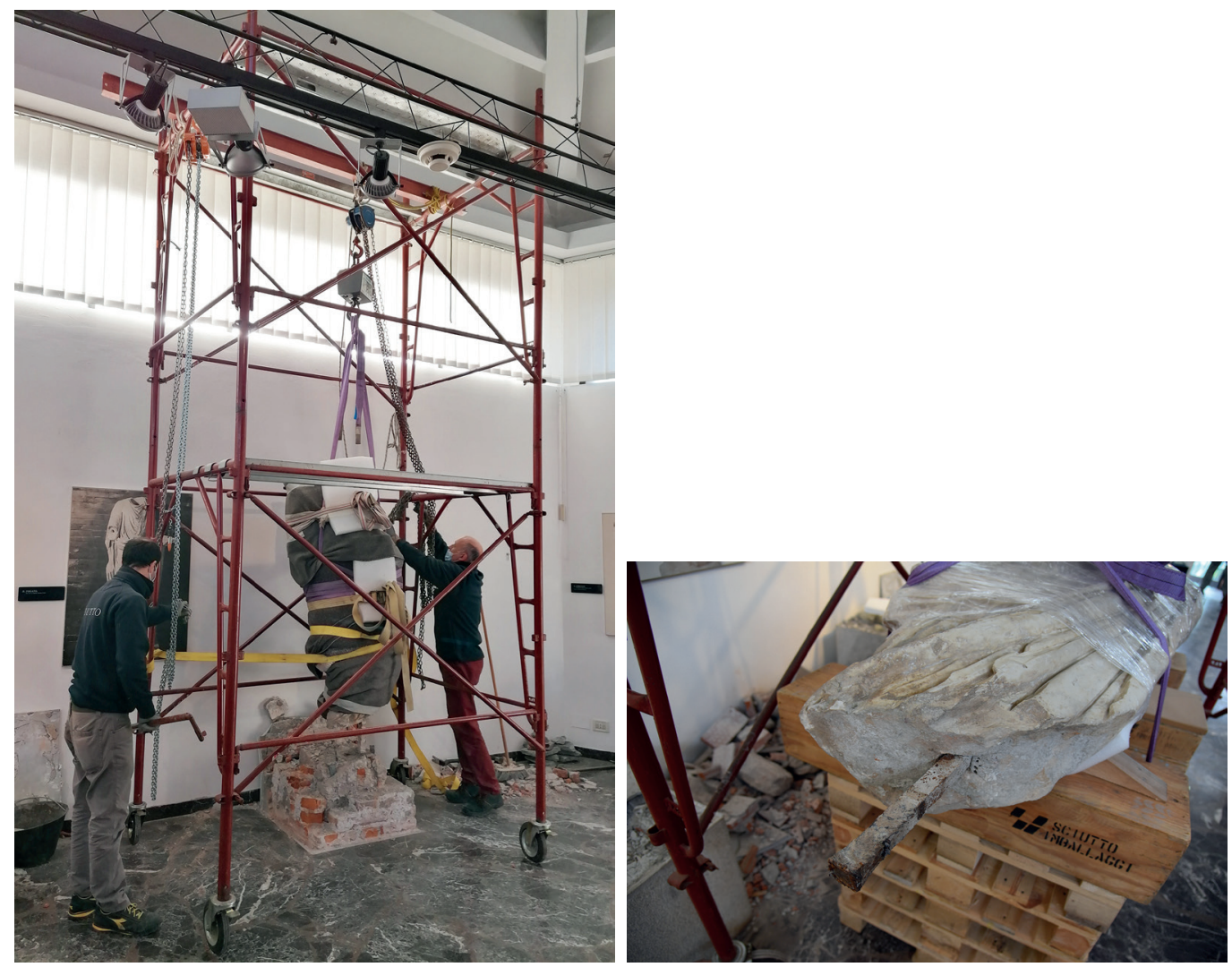

delle statue. I rilievi così ottenuti consentiranno di valutare aspetti di natura tecnica legati, ad esempio, alla statica dei singoli manufatti ed ai requisiti e caratteristiche strutturali che dovranno possedere i nuovi supporti espositivi, al fine di predisporne una corretta progettazione. Questi ultimi dovranno necessariamente essere aggiornati alle più recenti esigenze conservative legate al tema della sismicità del territorio, ma dovranno anche rispettare criteri di ritrattabilità e versatilità nei confronti di eventuali future e differenti esigenze di conservazione e di esposizione all'interno dell'area archeologica di Luni.

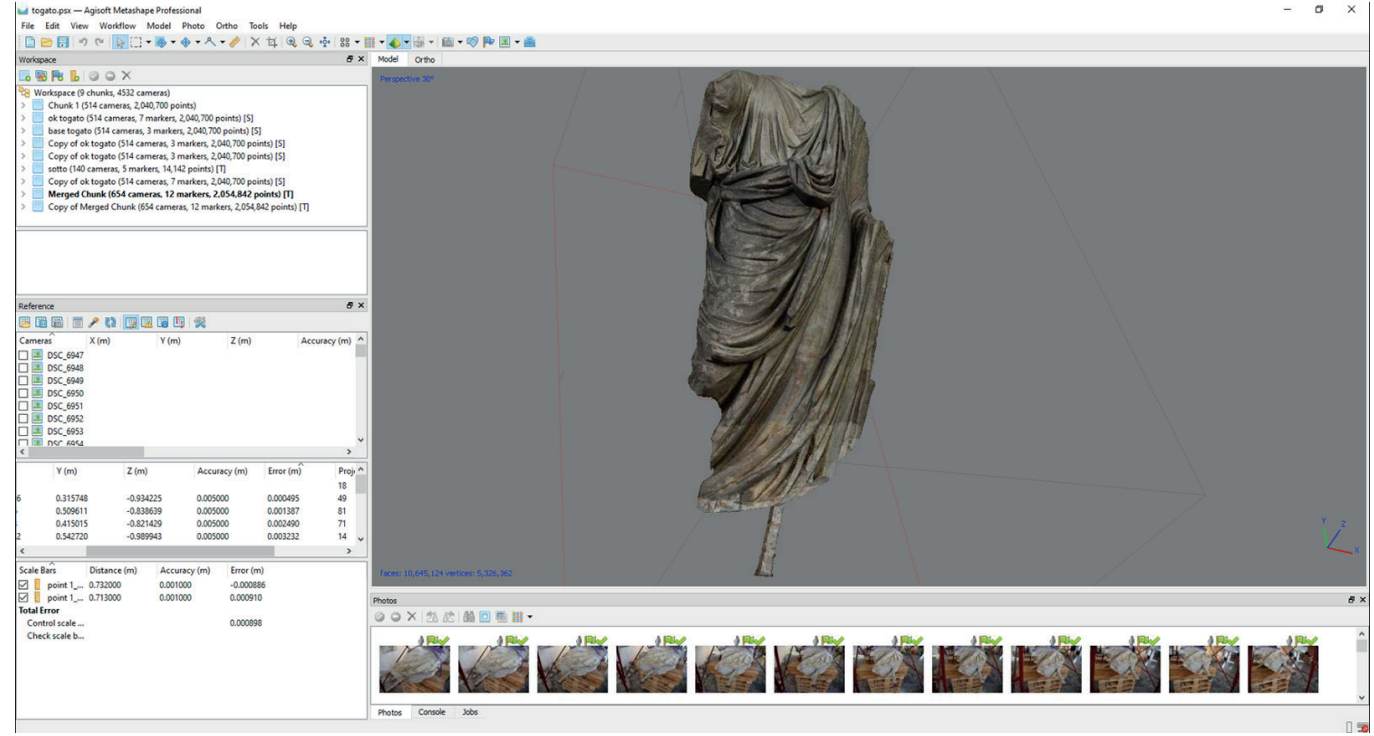

Fig. 10. Elaborazione dei modelli all'interno di Agisof Metashape Unione dei due rilievi effettuati in tempi distinti. 


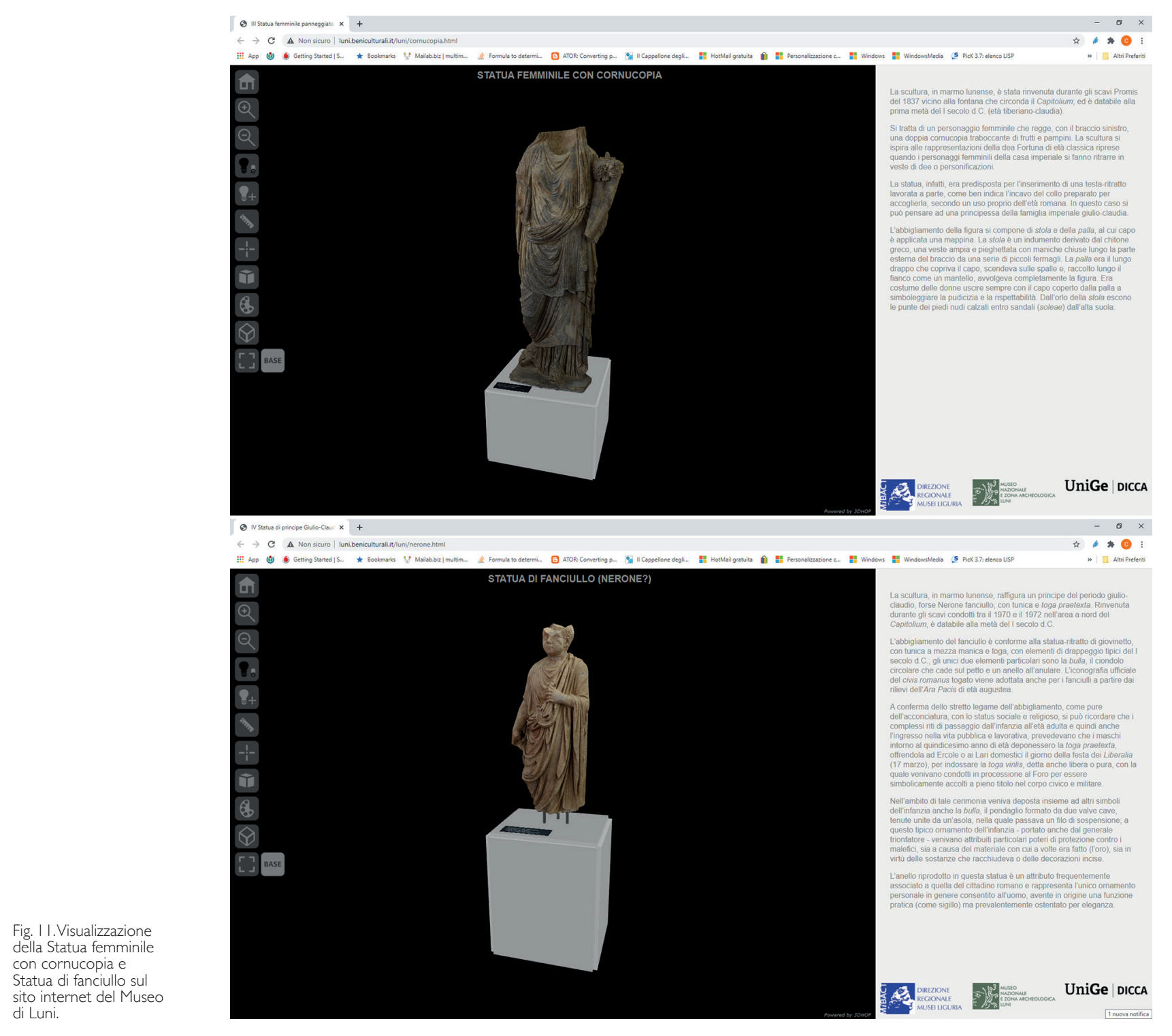

\section{Rilievo, rappresentazione e fruizione delle statue}

L'utilizzo di sistemi di digitalizzazione nel campo dei beni architettonici e storici è ormai una procedura consolidata. I modelli tridimensionali permettono infatti di creare una banca dati che può essere impiegata per documentazione, catalogazione, interventi di restauro e valorizzazione di opere spesso non facilmente accessibili. Tra gli esempi di utilizzo di rilievi tridimensionali per la gestione del restauro e della conservazione è possibile citare la Fontana del Nettuno a Bologna [Apollonio 20 I8] dove la digitalizzazione ha reso possibile la gestione delle informazioni utili al restauro in real time utilizzando un sistema web navigabile in 3D. All'inizio del 2000 anche il David di Michelangelo è stato acquisito digitalmente [Levoy 2000] ed il modello ottenuto è stato poi impiegato per verificare la condizione statica delle lesioni presenti nella gamba sinistra e nel tronco d'albero [Borri 2006]. Non mancano studi ed esempi sull'utilizzo di sistemi di navigazione 3D ed il potenziale che questo può avere da parte del pubblico [Quattrini 2020].

Partendo da queste considerazioni, il progetto qui presentato impiega le tecnologie oggi attuali per acquisire informazioni geometriche utili a più scopi. I modelli tridimensionali delle statue oggetto di questo contributo non solo consentiranno di guidare le scelte per 


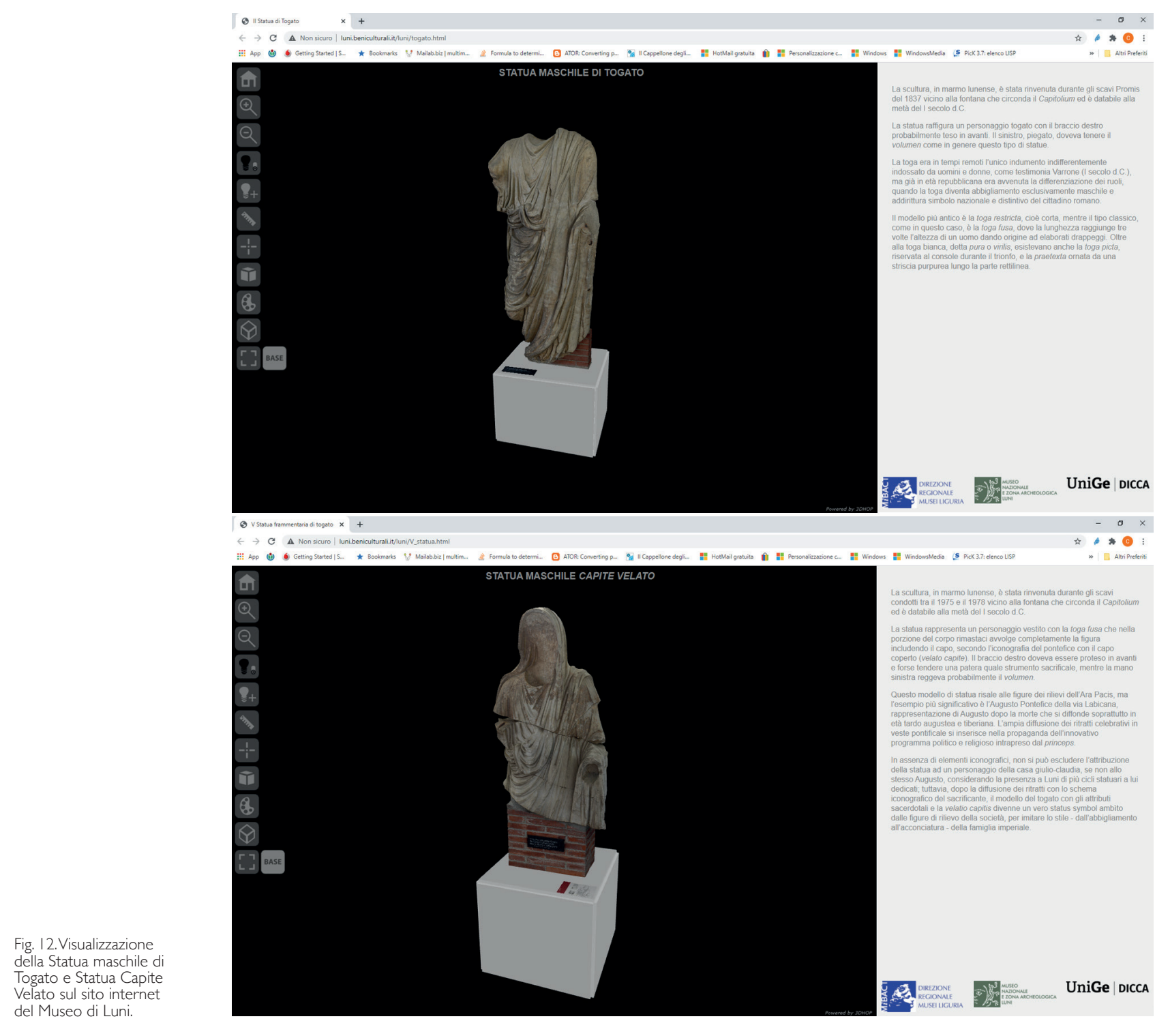

la definizione dei nuovi sistemi espositivi, ma costituiranno fin da subito un contributo fondamentale per la fruizione, valorizzazione e promozione delle sculture e dell'intero sito archeologico di Luni, almeno fino a quando sarà possibile tornare a goderne la visione dal vivo [5].

La prima scelta che è stata affrontata è stata quella della metodologia di rilievo da impiegare. La posizione delle statue all'interno del museo, la dimensione, la tipologia di materiale e la precisione richiesta sono state le variabili principali per la scelta della tecnica di rilievo da adottare. Tra sistemi a triangolazione, laser e fotogrammetrici, la scelta è ricaduta sulla tecnica dello Structure from Motion (SfM) per la sua facilità di utilizzo e bassi costi da sostenere per acquisire modelli tridimensionali. Inoltre, oggetti che presentano geometrie amorfe, superfici strutturate, molti bordi, molti punti e colorazioni distinte [Schaich 20 I3] sono particolarmente indicati per la tecnica SfM. Questa tecnica, ormai ampiamente utilizzate sia nel campo architettonico che archeologico, garantisce una ottima definizione geometrica ed un controllo dell'errore tale da rendere i modelli generati un'ottima banca dati da analizzare.

Come accennato precedentemente, le operazioni di rilievo si sono svolte in due differenti momenti dettati sia dalla posizione che alcune di queste statue assumevano all'in- 
terno del museo, sia dalla necessità di acquisire aree non visibili (fig. 9). Utilizzando la fotocamera full frame Nikon D750 sono state quindi acquisite centinaia di immagini sia in formato JPG che NEF. Quest'ultime sono state utilizzate per la correzione ed il bilanciamento dei colori dato che l'illuminazione degli ambienti non poteva essere controllata. I dati così raccolti sono stati elaborati prima all'interno del software Adobe Photoshop per creare mascherature puntuali delle statue, poi processate all'interno del software SfM Agisoft Metasape. II passaggio all'interno del software di grafica bitmap ha reso più agevole la creazione delle maschere necessarie alla successiva fase SfM, in quanto tra le funzioni presenti di Photoshop è presente una particolare tipologia di selezione che impiega algoritmi di intelligenza artificiale per selezionare oggetti in primo piano in modo accurato. Le immagini processate sono state inserite nella pipeline di Metashape ed hanno prodotto modelli ad alto numero di poligoni con texture di colore di 20000 $\times 20000$ pixel (fig. I0).

I modelli 3D ottenuti sono poi stati inseriti all'interno della piattaforma 3DHOP sviluppata dal Visual Computing Laboratoy di Pisa [6]. Sviluppata per far fronte alle esigenze del Cultural Heritage, la piattaforma impiega classiche pagine web, con aggiunta di componenti HTML e JAVASCRIPT, per rendere fruibile modelli tridimensionali molto complessi tramite i più comuni browser web. Nel caso specifico delle statue, dopo essere state verificate e modificate le texture secondo le istruzioni indicate, sono state apportate minime modifiche all'interfaccia grafica in modo tale da poter personalizzare l'esperienza visiva dell'utente finale. In particolare si è reso necessario aggiungere un pannello laterale nel quale mostrare le informazioni principali dell'opera rappresentata, oltre all'inserimento di un pulsante per nascondere il basamento cementizio ormai demolito. Le altre funzioni che il sistema implementa di default sono state tutte rese fruibili (sezione, illuminazione, cambio di visualizzazione da prospettico a assonometrico, misura, etc.) in modo da rendere l'utente finale più interattivo e curioso nella navigazione di queste statue (figg. II, 12).

\section{Conclusioni}

Il lavoro presentato costituisce il primo passo di un progetto di più ampio respiro il cui fine principale è quello di migliorare la fruizione del sito archeologico di Luni. La nascita del nuovo museo, con la conseguente riorganizzazione degli spazi e delle collezioni, e il preciso momento storico che impedisce la visita in presenza da parte dei turisti, ha portato alla necessità di mettere in atto nuove modalità di coinvolgimento del pubblico. La possibilità di integrare le nuove tecnologie nei processi di valorizzazione del sito potrebbe inoltre consentire di riunire, ricontestualizzandole in un unico ambiente anche se virtuale, le numerose opere scoperte nel sito di Luni, ma che a causa della complessa storia dell'esplorazione dell'antico centro, sono oggi diffuse in varie sedi espositive sia pubbliche che private.

\section{Note}

[I] Una rassegna vasta, seppure non completa, della bibliografia dedicata a Luni è presente in <http://www.luni.beniculturali.it/ index.php?it/285/bibliografia> (consultato il 26 febbraio 2021).

[2] Non sono state effettuate analisi petrografiche, ma sulla base di osservazioni autoptiche è possibile attribuirle a marmi locali.

[3] Ad eccezione della statua maschile panneggiata del tipo in nudità eroica. Tale scultura è dotata di un basamento in ghisa.

[4] Era comunque evidente una eterogeneità di soluzioni adottate: con perni in metallo, attraverso puntelli in cortina laterizia sagomati e malta cementizia impiegata all'interfaccia della superficie di appoggio, oppure affogando direttamente la superficie di appoggio delle statue con malta cementizia, poi occultata con il rivestimento in lastre di marmo.

[5] Sito di riferimento per la visione delle statue: <http://www.luni.beniculturali.it/index.php?it/ /48/news/ / 09/modelli-3d-opere-statuarie $>$ (consultato il 27 febbraio 2021).

[6] Per maggiori informazioni visitare il sito dedicato 3DHOP: http://vcg.isti.cnr.it/3dhop/index.php (consultato il 27 febbraio 202I). 


\section{Riferimenti bibliografici}

AA.W. (1983). Marmora Lunensia erratica. Mostra fotografica delle opere lunensi disperse. Sarzana.

Apollonio F.I., Basilissi V. Callieri M. et al. (2017). A 3D-centered information system for the documentation of a complex restoration intervention. In Journal of Cultural Heritage, No. 29, January-February 20 I 8, pp 89-99. <https://www.sciencedirect.com/ science/article/abs/pii/S I 296207417301905> (consultato il 27 febbraio 202I).

Borri A., Grazini A. (2006). Diagnostic analysis of the lesions and stability of Michelangelo's David. In Journal of Cultural Heritage, 7, pp. 273-285. <https://www.sciencedirect.com/science/article/abs/pii/SI 296207406000768> (consultato il 27 febbraio 202I).

De Pascale A., Gandolfi D. (a cura di). (20l7). Colligite Fragmenta 2. Atti del convegno di Bordighera 25-26 febbraio 20I2, Genova: Edizioni De Ferrari

Durante A.M., Gervasini L. (2017). II collezionismo dinastico in Liguria: il caso di Luni. In De Pascale A., Gandolfi. D. Colligite fragmenta, vol. 2, pp. $129-139$.

Frova A. (1983). Ritrattistica e scultura a Luni. In Rivista di Studi Liguri, XLIX, I -4, pp. 37-84.

Levoy M., Pulli K., Curless B., et al. (2000). The Digital Michelangelo Project: 3D Scanning of Large Statues. In Proceedings of ACM SIGGRAPH 2000, pp. I31-144.

Lusuardi S., Massari G., Rossignani M.P. (1980). II nuovo allestimento del Museo di Luni: progetto e prime realizzazioni. In Quaderni Centro Studi Lunensi, No. 4-5, 1979-1980, pp. 3-32.

Mancusi M., Chiarenza N. (2018). Attività e ricerche del MiBACT a Luni. In Quaderni del Centro Studi Lunensi, vol. II n.s., Pp. | |-36.

Schaich M. (20I3). Combined 3D scanning and photogrammetry surveys with 3D database support for archaeology \& cultural heritage. In A practice report on ArcTron's information system aSPECT3D, Proc. Photogrammetric Week 20I3, D. Fritsch (Ed.) Wichmann, Berlin/Offenbach, pp. 233-246.

\section{Autori}

Carlo Battini, Università degli Studi di Genova, carlo.battini@unige.it

Marcella Mancusi, Ministero per i Beni e le Attività Culturali e per il Turismo, marcella.mancusi@beniculturali.it Mauro Stallone, Ministero per i Beni e le Attività Culturali e per il Turismo, mauro.stallone@beniculturali.it

Per citare questo capitolo: Battini Carlo, Mancusi Marcella, Stallone Mauro (2021). Rilievo tridimensionale e virtualizzazione di sculture in marmo del Museo Archeologico Nazionale di Luni/Three-dimensional Survey and Virtualization of Marble Sculptures from the National Archaeological Museum of Luni In Arena A Arena M. Mediati D. Raffa P. a cura di) Connettere Un disegno per annodare e tessere. Linguaggi Distanze Tecnologie. Atti del $42^{\circ}$ Convegno internazionale dei Docenti delle Discipline della Roppresentt Distances Technologies. Proceedings of the 42th International Conference of Representation Disciplines Teachers. Milano: FrancoAngeli, pp. $2014-2035$. 


\title{
Three-dimensional Survey and Virtualization of Marble Sculptures from the National Archaeological Museum of Luni
}

\author{
Carlo Battini \\ Marcella Mancusi \\ Mauro Stallone
}

Abstract

This contribution aims to describe the choices and operational methodologies that led to the three-dimensional acquisition of five marble sculptures until now preserved in the National Archaeological Museum of Luni. Thanks to the Framework Agreement signed between the Direzione Regionale of Liguria and the Department of Civil, Chemical and Environmental Engineering (DICCA), University of Genoa, it was possible to activate a specific implementation agreement within which the objectives were defined and the operating procedures for the execution of 3D surveys. This intervention arises as a consequence of the decision to demolish the Lunense museum and the need to remove all the finds kept in it. The first phase had in fact the purpose of documenting the state of affairs of the works and of their particular display system that would have been necessary to remove in anticipation of the movement. The subsequent integration of the acquisitions with the support surfaces, not visible before the demolition of the support structures, made it possible to record all the information necessary for the correct design of suitable supports useful for their future fitting. The same models were then made accessible via the web on an open source platform

Keywords

Luni, museum, sculptures, structure from motion, documentation.

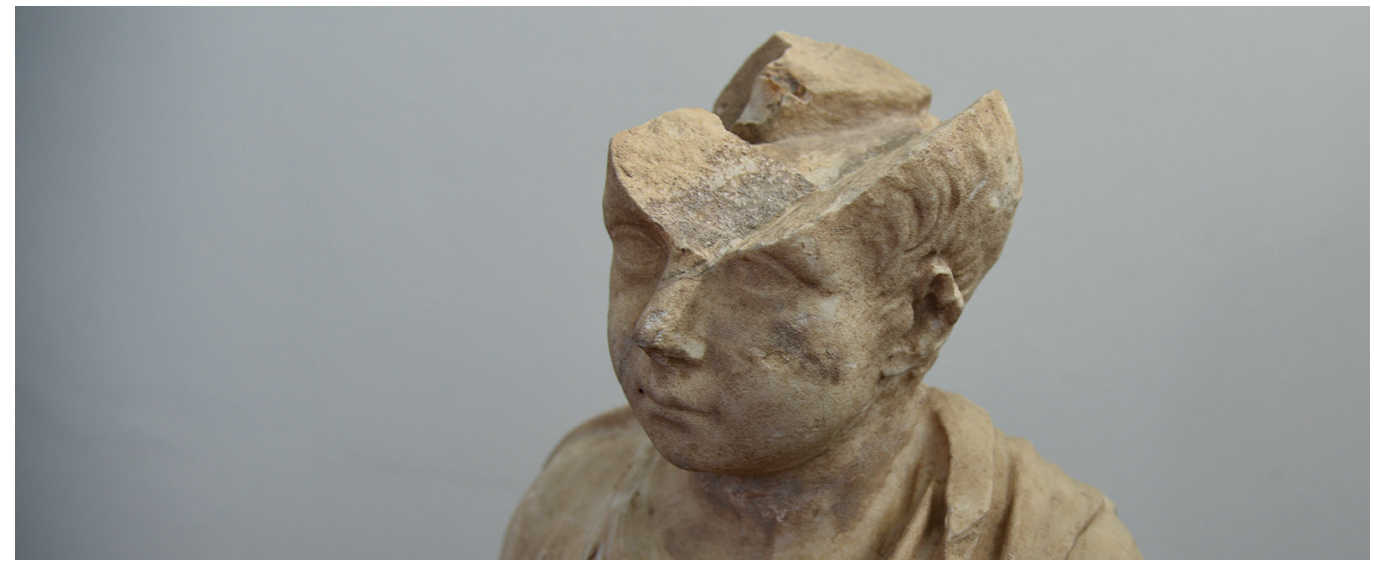




\section{Introduction}

The archaeological site of Luni is located in the extreme Levant of Liguria and preserves the remains of the Roman colony of Luna, founded in I77 BC. and inhabited continuously until the early thirteenth century.

During the imperial period the city acquires fame and wealth through the exploitation of marble quarries of the Apuan Alps that fall within its territory; from there the marble is exported throughout the empire, especially in Rome.

Despite the intense spoliation that took place in ancient times, there is a discrete corpus of figured sculptures which is now distributed in various exhibition venues due to the complex history of the exploration of the center which, which began in the early decades of the 19th century, led to the formation of important private collections [De Pascale, Gandolfi 20 I7]. Since the mid-1900s, archaeological research has begun - and is still in progress - conducted by the body for the protection of that, now the Ministry of Culture, which has given rise on the one hand to a vast scientific bibliography [I], from the other the formation of the archaeological and museum intended for public use, as they are currently.

\section{The marble sculptures}

The statues, subject of the 3D survey, have stories quite different, but they are united by the local marble used for their execution [2] and the fact that they were created in a period straddling the end of the century. B.C. and the middle of the following century. This period corresponds to the time of maximum flowering Luni as a result of the wealth derived from the intensive exploitation of the marble quarries, the city faces a profound transformation in the name of urban and architectural monumentality. The statuary also contributes to this result, mainly used to embellish public spaces of various kinds.

Specifically, the sculptures in question reproduce four male subjects, three of which are adults, and one female; all are partially incomplete and -with the exception of a single caseare faceless.

Among the most ancient finds are the female statue with cornucopia and the male statue with toga (fig. I), both of which came to light in 1837 during the explorations conducted by the architect Carlo Promis, Inspector of the Monuments of Antiquities of the Royal Museums, in the land owned by the Marquis Angelo Remedi. The recovery area is that which over a century later was identified as the fountain basin which develops on three sides around the Capitoline temple (fig. 2). The two sculptures are selected for the Savoyard collections, but exhibited in the Turin Museum of Antiquities only in I 878 and, shortly thereafter, in the IV National Exhibition of Fine Arts held in the same city; after almost a century, in 1963, they return to Luni for the inauguration of the museum under construction [Durante, Gervasini 2017].

The female statue, dressed in an elegant robe and cloak, portrays, in a manner often used during the empire for propaganda purposes, a character of the imperial family associating it with the image of a divinity or a personification of an abstract concept, in this case Abundantia or Fortuna due to the presence of the double cornucopia from which fruits emerge (fig. 3) [Frova 1983, pp. 73-75, fig. 28; Marmora Lunensia erratica, pp. 5I-53].The recognition of the character is entrusted to the face-portrait of which the recess for housing remains clearly visible.

A similar cavity is also preserved in the male statue wearing a thickly draped toga (fig. 4) and reproduces a precise iconographic scheme in which one arm is bent to support the volumen while the other is stretched forward [Frova 1983, pp. 76-77, fig. 30; Marmora Lunensia erratica, pp. 54-55].

More linear is the fate of the sculptures of the Capite Velato and of the prince giulio-cluadio found following the important excavation campaigns carried out in the 1970s, respectively to the east and north of the Capitolium, in areas contiguous to those from which the statues described above. 

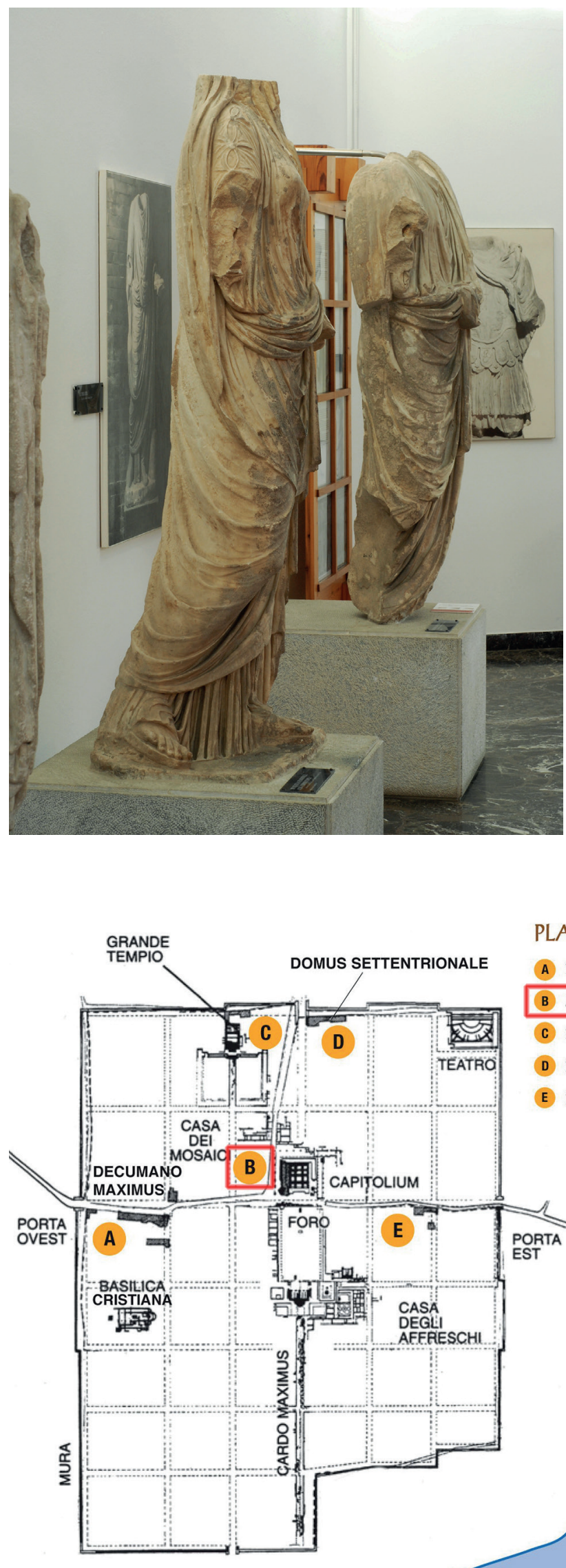

PLANIMETRIA DELLA CITTÁ DI LUNI

A Sala conferenze e uffici

B Museo Archeologico Nazionale e sezione dedicata al Capitolium

C Sezione dell'architettura sacra - "ll Grande Tempio"

D Sezione epigrafica

E Sezione dell'edilizia privata

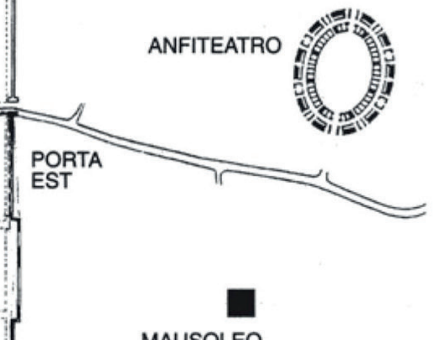

MAUSOLEO 


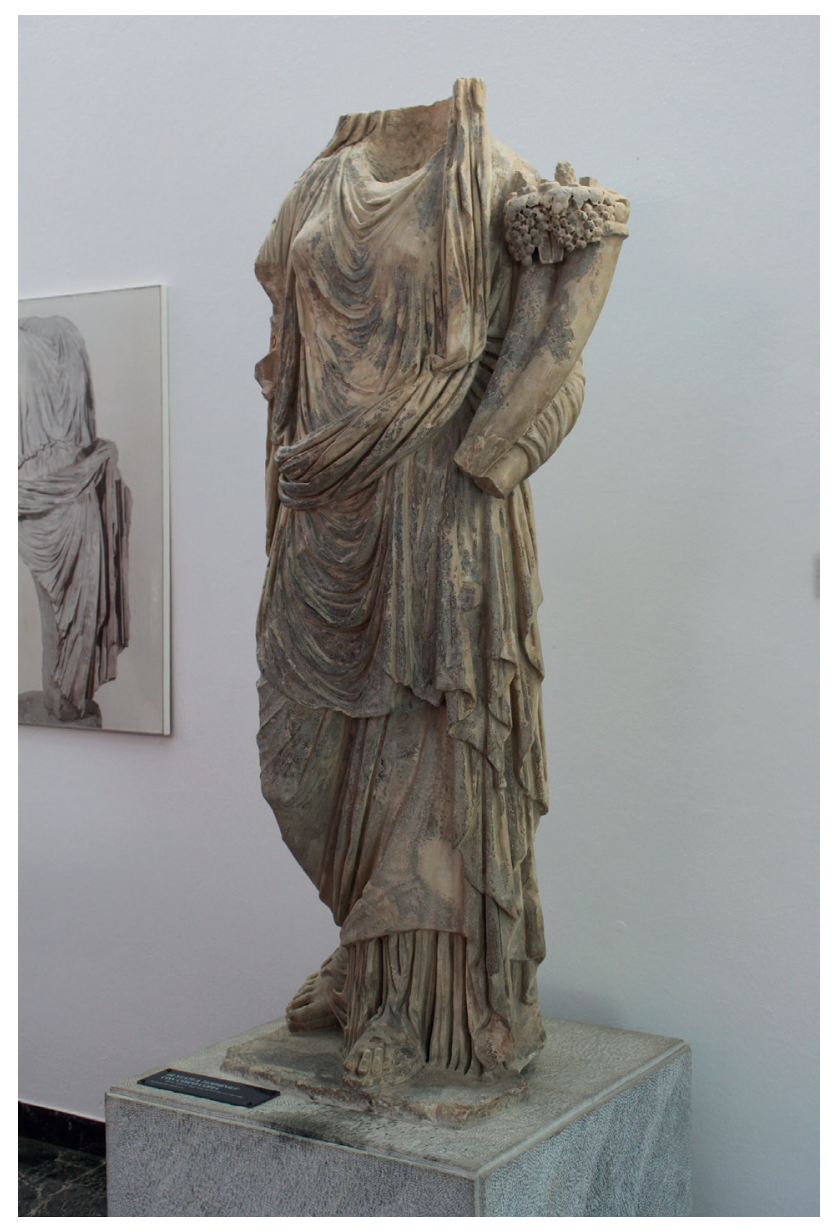

The Capite velato, without the lower half [Frova 1983, p. 78, note no. 59], has features which permit its identification as pontifex the act of performing a sacrifice, ritual is precisely that it was necessary to take place in an the head covered. Also in this case the loss of the face does not allow us to establish whether the person depicted was Augustus or a successor of him; it should also be borne in mind that this iconography was very successful even outside the imperial circle.

The statue of a boy with a bulla - a typical childhood ornament -, which expresses his status by means of the ring visible on the left ring finger, most likely belonged to a young prince (fig. 5).

The last sculpture of the group became part of the museum only in 2016 after being stolen from those who held it illegally. The place of origin is unknown, however the marble with which it is made is from Luni. The statue, without the upper part, falls within the typology of virile statues in heroic nudity with which wealthy citizens, emperors and divinities are portrayed indifferently (fig. 6) [Mancusi, Chiarenza 2018, pp. 21, 22].

\section{The birth of the collaboration project}

The museum, intended to collect and exhibit the main artifacts found in the Lunense archaeological area, was inaugurated in 1964 on a project by the architect Aldo Grillo. Since its inauguration it has undergone several changes and modifications in its exhibition layout and in the selection of finds [Lusuardi, Massari, Rossignani 1980], while maintaining substantially unchanged until today the setting up of the large statuary inside the large room polygonal south of the building (fig. 7). Following the Resolution of the Regional Council n. 216 of 


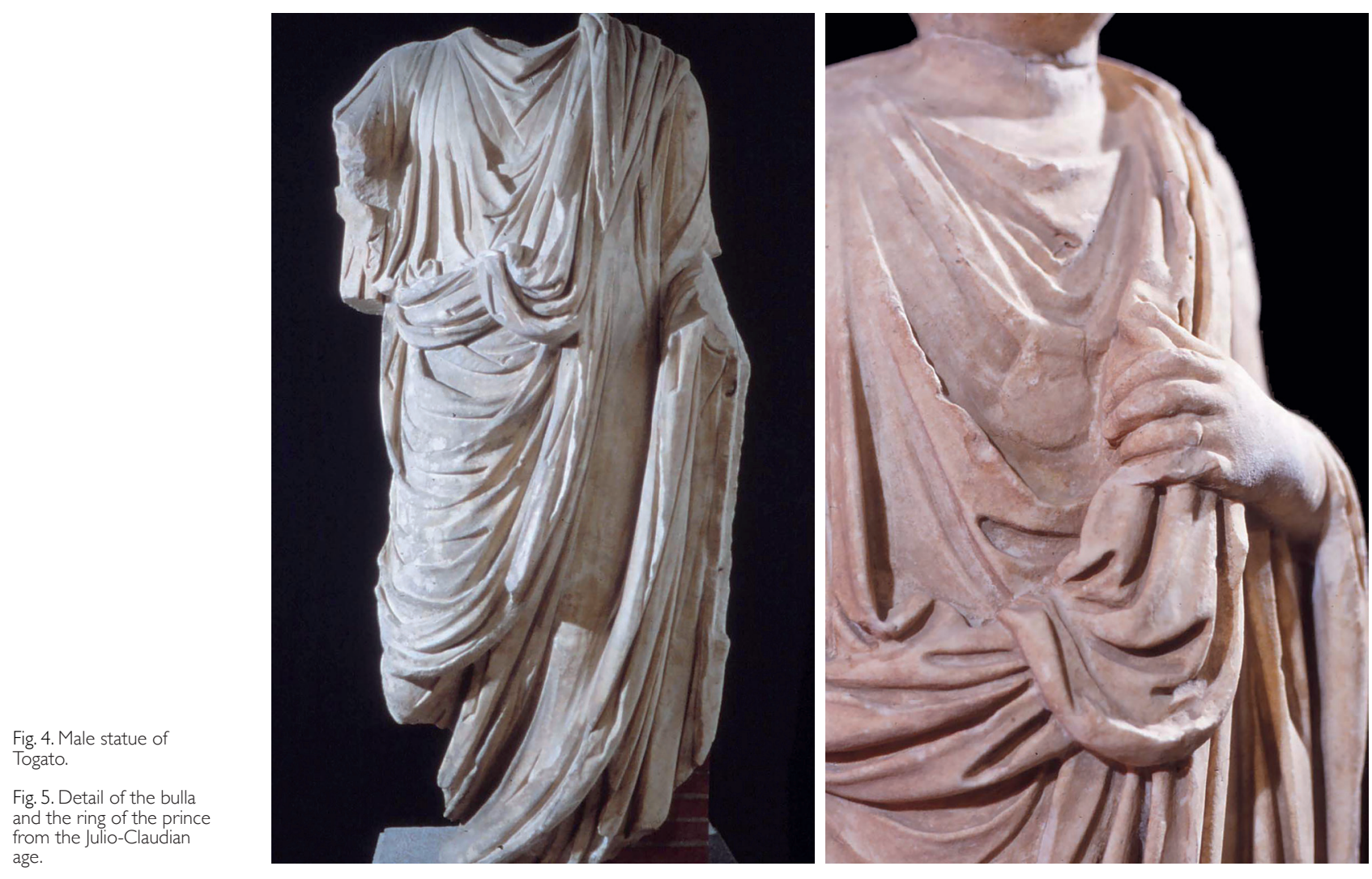

2017, which raised the risk class of the Luni area, it was necessary to start investigations to define the seismic risk of all buildings in the archaeological area. The analysis of the technicians, considering the particular nature of the museum building, also linked to the peculiarity of insisting directly on the level of the archaeological floor as well as in correspondence with important architectural structures, highlighted the impossibility of adapting the Museum to the current anti-seismic legislation.

In light of these data and in order to guarantee the safety of visitors and workers, the building was closed to the public in 2018 . Hence the need to identify an alternative solution that would involve moving the finds, setting up new spaces exhibition areas and the demolition of the building declared no longer accessible.

In anticipation of the necessary intervention of the building demolition, an articulated project aimed at the museum emptying and contextual was prepared handling of all the works contained therein. In the case of the five stone sculptures, it was decided to deepen their study and documentation, considering the very few archive information that emerged in relation to the history of previous interventions, the restoration methodologies and the methods of preparation. The statues, in fact, had been positioned on concrete parallelepipeds covered with marble [3] slabs which sometimes concealed the real constraint system at the support bases [4].

On the basis of a Framework Agreement, stipulated between the Direzione Regionale dei Musei (DRM) of Liguria and the Department of Civil, Chemical and Environmental Engineering (DICCA) of the University of Genoa, it was possible to activate a specific agreement for the three-dimensional survey of the five stone sculptures using no-contact instrumentation. One of the objectives of the project was to acquire all the information relating to the current state of the works in order to document their state of conservation and record their conservation history, prior to the emptying and subsequent demolition of the museum. A first campaign of acquisitions was therefore launched which had as its object the survey of the stone surfaces and the bases that made up the display system. 
Fig. 6. Male statue in

heroic nudity, orthophoto.
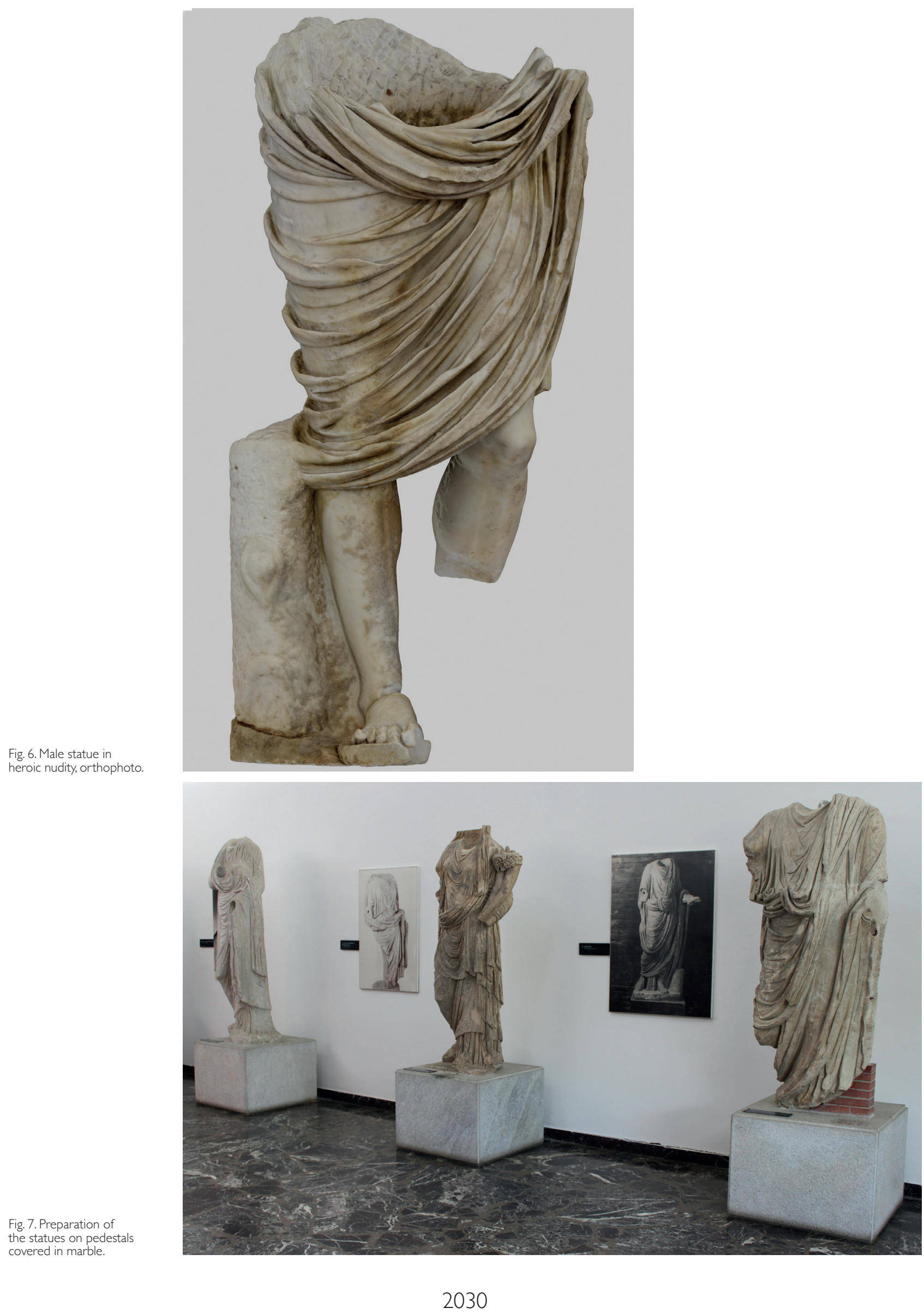
Fig. 8. Step handling of the statues after the partial demolition of the pedestals.

Fig. 9. Area not detectable before the pedestal was demolished.
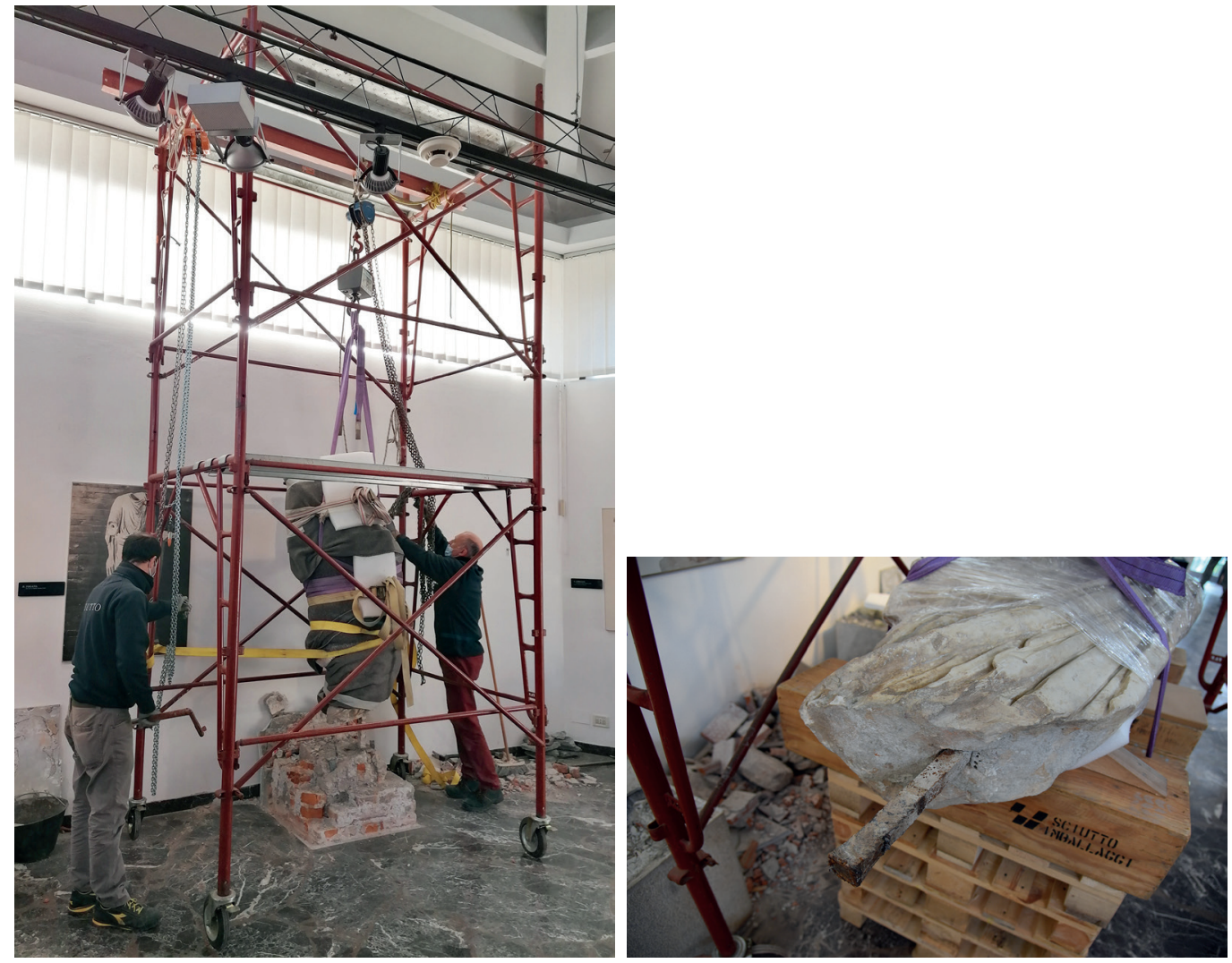

After the demolition of the pedestals, necessary to move the finds (fig. 8), it was possible to proceed with the second campaign of acquisitions for the detection of the support surfaces in order to complete the three-dimensional models of the statues. The surveys thus obtained will allow to evaluate aspects of a technical nature linked, for example, to the statics of the individual artifacts and to the requirements and structural characteristics that the new display supports must possess, in order to prepare a correct design. The latter must necessarily be updated to the most recent conservation needs linked to the theme of

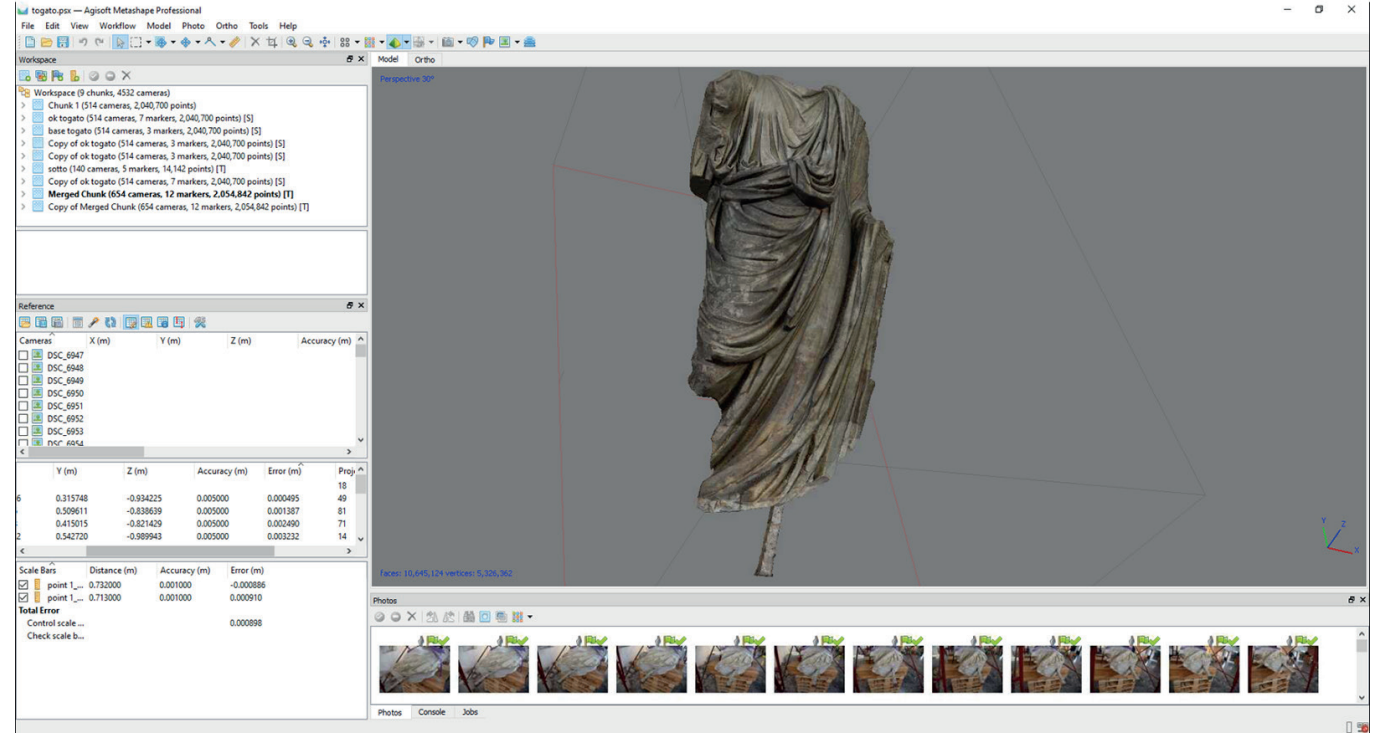

Fig. 10. Model processing within Agisoft Metashape Union of the two surveys carried out at different times. 


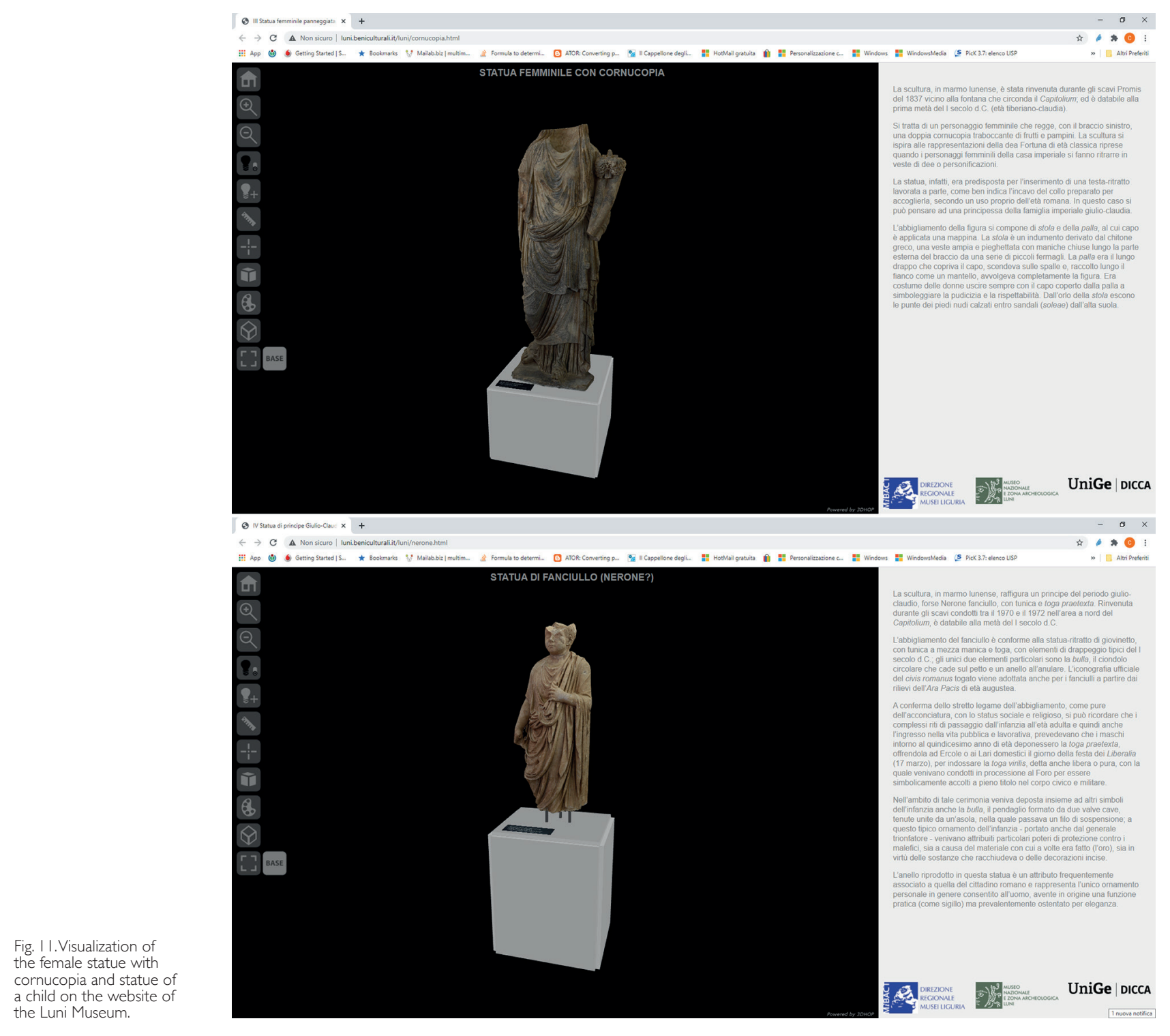

the seismicity of the territory, but they must also comply with criteria of retractability and versatility in relation to any future and different conservation and exhibition needs within the archaeological area of Luni.

\section{Survey, representation and fruition of statues}

The use of digitization systems in the field of architectural and historical heritage is now a consolidated procedure. In fact, the three-dimensional models make it possible to create a database that can be used for documentation, cataloging, restoration and enhancement of works that are often not easily accessible. Among the examples of the use of three-dimensional surveys for the management of restoration and conservation, it is possible to mention the Fountain of Neptune in Bologna [Apollonio, 20 I 8] where digitization has made it possible to manage information useful for restoration in real time using a web system navigable in 3D.

At the beginning of 2000, Michelangelo's David was also digitally acquired [Leroy, 2000] and the model obtained was then used to verify the static condition of the lesions present 


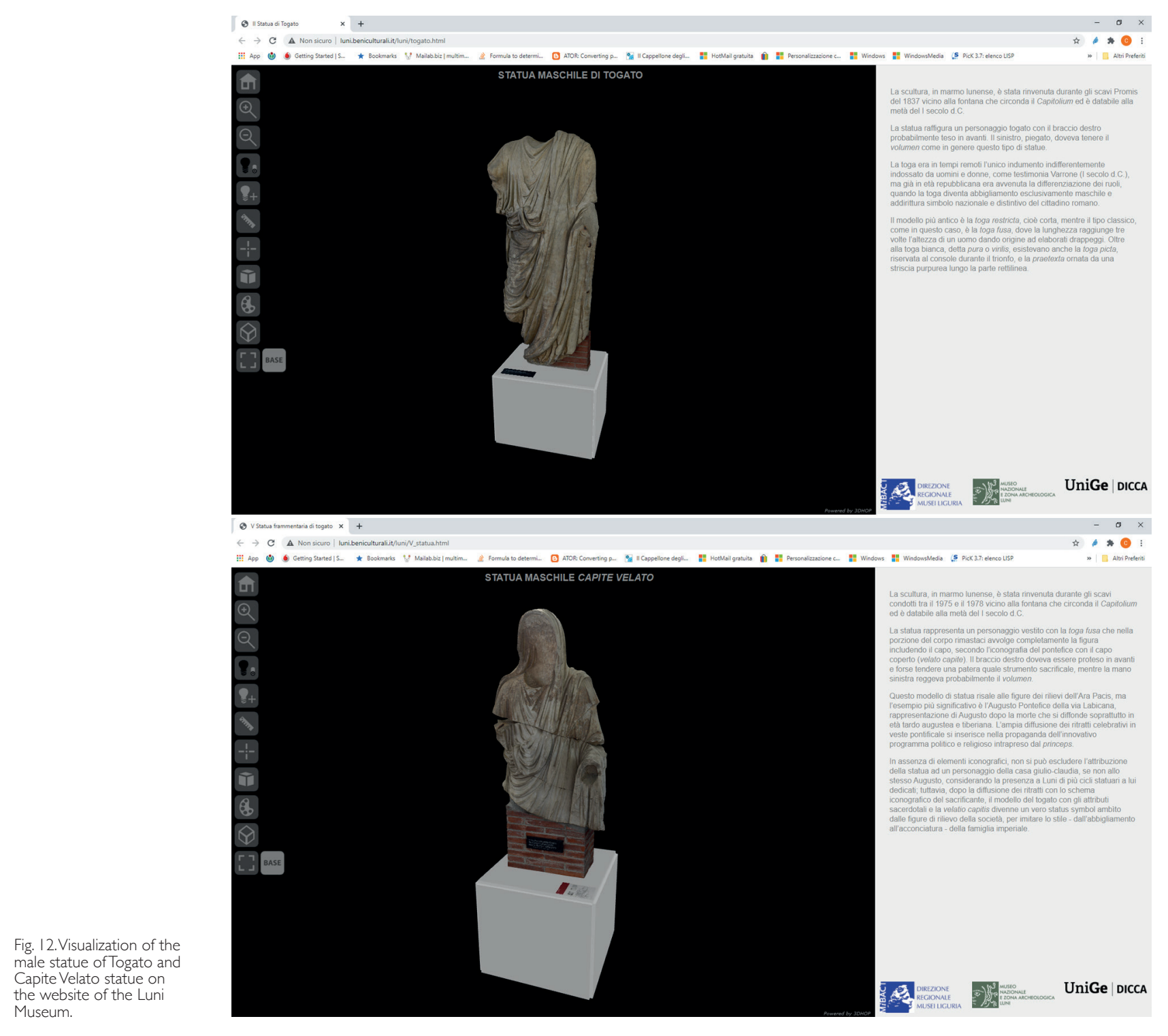

in the left leg and in the tree trunk [Borri, 2006]. There are also studies and examples on the use of 3D navigation systems and the potential that this can have from the public [Quattrini, 2020].

Starting from these considerations, the project presented here uses today's technologies to acquire geometric information useful for several purposes. The three-dimensional models of the statues, the subject of this paper, will not only guide the choices for the definition of the new exhibition systems, but will immediately constitute a fundamental contribution for the use, enhancement and promotion of the sculptures and the entire archaeological site of Luni, at least until it will be possible to return to enjoy live viewing [5].

The first choice that has been addressed has been to the methodology that was to be used. The position of the statues within the museum, the size, the type of material and the required precision were the main variables for the choice of the survey technique to be adopted. Between triangulation, laser and photogrammetric systems, the choice fell on the Structure from Motion (SfM) technique for its ease of use and low costs to be incurred to acquire three-dimensional models. Furthermore, objects with amorphous geometries, structured surfaces, many edges, many points and distinct colors [Schaich, 2013] are particularly suitable for the SfM technique. This technique, now 
widely used in both the architectural and archaeological fields, guarantees excellent geometric definition and error control that makes the generated models an excellent database to be analyzed

As mentioned previously, the survey operations took place in two different moments dictated both by the position that some of these statues assumed within the museum, and by the need to acquire non-visible areas (fig. 9). Using the Nikon D750 full frame camera, hundreds of images in both JPG and NEF formats were then captured. These have been used for color correction and balancing since the room lighting could not be controlled. The data collected were processed before in the Adobe Photoshop software to create precise masking of the statues, then processed within the SFM Agisoft Metasape software. The passage within the bitmap graphics software has made it easier to create the masks necessary for the subsequent SfM phase, since among the functions present in Photoshop there is a particular type of selection that uses artificial intelligence algorithms to select objects first plan accurately. The processed images were fed into the Metashape pipeline and produced high polygon count models with color textures of 20,000 $\times 20,000$ pixels (fig. I0).

The 3D models obtained were then inserted into the 3DHOP platform developed by the Visual Computing Laboratoy of Pisa [6]. Developed to meet the needs of Cultural Heritage, the platform uses classic web pages, with the addition of HTML and JAVASCRIPT components, to make very complex three-dimensional models usable through the most common web browsers. In the specific case of the statues, after having checked and modified the textures according to the instructions indicated, minimal changes were made to the graphic interface in order to customize the visual experience of the end user. In particular, it was necessary to add a side panel in which to show the main information of the work represented, in addition to inserting a button to hide the demolished concrete base. The other functions that the system implements by default have all been made usable (section, lighting, change of view from perspective to axonometric, measurement, etc.) in order to make the end user more interactive and curious in navigating these statues (figs. II, I2).

\section{Conclusion}

The work presented constitutes the first step of a broader project whose main purpose is to improve the use of the archaeological site of Luni. The birth of the new museum, with the consequent reorganization of the spaces and collections, and the precise historical moment that prevents the visit in presence by tourists, has led to the need to implement new ways of involving the public. The possibility of integrating new technologies into the site's enhancement processes could also make it possible to bring together, recontextualizing them in a single environment, albeit virtual, the numerous works discovered in the Luni site, but which due to the complex history of the exploration of the ancient center, are now widespread in various public and private exhibition venues.

\section{Notes}

[I] A vast, although not complete, review of the bibliography dedicated to Luni is present in http://wmw.luni.beniculturali.it/ index.php?it/285/bibliografia (accessed 2021, February 26).

[2] No petrographic analyzes have been carried out, but on the basis of autoptic observations it is possible to attribute them to local marbles.

[3] With the exception of the draped male statue of the heroic naked type. This sculpture is equipped with a cast iron base.

[4] However, a heterogeneity of solutions was evident: with metal pins, through shaped brick curtain props and cement mortar used at the interface of the support surface, or by directly drowning the resting surface of the statues with cement mortar, then concealed with the coating in marble slabs.

[5] Reference site for viewing the statues: <http://www.luni.beniculturali.it/index.php?it//48/news/ I09/modelli-3d-opere-statuarie $>$ (accessed 2021, February 27).

[6] For more information visit the dedicated 3DHOP website: http://vcg.isti.cnr.it/3dhop/index.php (viewed on 202I, February 27 ). 


\section{References}

AA.W. (1983). Marmora Lunensia erratica. Mostra fotografica delle opere lunensi disperse. Sarzana.

Apollonio F.I., Basilissi V. Callieri M. et al. (2017). A 3D-centered information system for the documentation of a complex restoration intervention. In Journal of Cultural Heritage, No. 29, January-February 20 I 8, pp 89-99. <https://www.sciencedirect.com/ science/article/abs/pii/S1 296207417301905> (accessed 2021 , february 27).

Borri A., Grazini A. (2006). Diagnostic analysis of the lesions and stability of Michelangelo's David. In Journal of Cultural Heritage, 7. pp. 273-285. <https://www.sciencedirect.com/science/article/abs/pii/S I 296207406000768> (accessed 2021, february 27).

De Pascale A., Gandolfi D. (a cura di). (2017). Colligite Fragmenta 2. Atti del convegno di Bordighera 25-26 febbraio 20।2, Genova: Edizioni De Ferrari

Durante A.M., Gervasini L. (2017). II collezionismo dinastico in Liguria: il caso di Luni. In De Pascale A., Gandolfi. D. Colligite fragmenta, vol. 2, pp. 129-139.

Frova A. (1983). Ritrattistica e scultura a Luni. In Rivista di Studi Liguri, XLIX, I-4, pp. 37-84.

Levoy M., Pulli K., Curless B., et al. (2000). The Digital Michelangelo Project: 3D Scanning of Large Statues. In Proceedings of ACM SIGGRAPH 2000, pp. I31-144.

Lusuardi S., Massari G., Rossignani M.P. ( 1980). II nuovo allestimento del Museo di Luni: progetto e prime realizzazioni. In Quaderni Centro Studi Lunensi, No. 4-5, 1979-1980, pp. 3-32.

Mancusi M., Chiarenza N. (20 I8). Attività e ricerche del MiBACT a Luni. In Quaderni del Centro Studi Lunensi, vol. II n.S., Pp. | |-36.

Schaich M. (20 I3). Combined 3D scanning and photogrammetry surveys with 3D database support for archaeology \& cultural heritage. In A practice report on ArcTron's information system aSPECT3D, Proc. Photogrammetric Week 20 I3, D. Fritsch (Ed.) Wichmann, Berlin/Offenbach, pp. 233-246.

\section{Authors}

Carlo Battini, Università degli Studi di Genova, carlo.battini@unige.it

Marcella Mancusi, Ministero per i Beni e le Attività Culturali e per il Turismo, marcella.mancusi@beniculturali.it Mauro Stallone, Ministero per i Beni e le Attività Culturali e per il Turismo, mauro.stallone@beniculturali.it

To cite this chapter. Battini Carlo, Mancusi Marcella, Stallone Mauro (2021). Rilievo tridimensionale e virtualizzazione di sculture in marmo del Museo Archeologico Nazionale di Luni/ Three-dimensional Survey and Virtualization of Marble Sculptures from the National Archaeologica Museum of Luni. In Arena A Arena M. Mediati D. Raffa P (a cura di) Connettere. Un disegno per annodare e tessere Lingugogi Distanze Tecnologie. Atti del $42^{\circ}$ Convegno lnternozionale dei Docenti Raffa Pla cura dello Raptrese Distances Technologies. Proceedings of the 42th International Conference of Representation Disciplines Teachers. Milano: FrancoAngeli, pp. 20I4-2035. 